\title{
The Awareness of Various Theoretical Dimensions of Cultural Variability in Enhancing a Language Educatorr Classroom Practice
}

\author{
Xinyi Yang * \\ Xi'an Eurasia University, Xi'an, Shaanxi 710065
}

\begin{abstract}
With the great impact of globalization, expanding immigration and economic transactions, our world has become more diverse than it used to be. In view of that, cross-cultural interaction has become more frequent and inevitable. This can even be reflected in the teaching practice among language educators and students from different cultural backgrounds. As Gay (2000) noticed, culture is at the heart of all we do in the name of education, whether that is curriculum, instruction, administration, or performance assessmentme more frequent and inevitable. ThiHofstede (2001) that ) that art of all we do in the name of education, whether that is curriculum, instruction, administration, or performance assessmentme more frequent andvarious and dynamic cultural contexts, language educators have to come up with some feasible approaches to make their teaching practice more effective. Keywords: Language Educatorr;Cultural variability;Classroom Practice
\end{abstract}

Based on Hofstede's studies (2001), there are various cultural dimensions impacting the effectiveness of language educators' classroom practice among students from different cultural backgrounds. However, to what extent language educators could integrate those dimensions well into their teaching to guarantee a more effective classroom practice will be discussed through this essay.

\section{Understanding of Classroom Practice by Language Educators}

First of all, language educators' awareness of individualism and collectivism among their intercultural students can contribute to a more effective classroom practice. As Hofstede (1986) cited, compared with students from individualist societies, who are more inclined to individual interests and open to confrontations in class, students from collectivist societies are prone to maintain a harmonious group relationship and try to avoid interpersonal conflict. Especially, the maintenance of hrough this essay.cted in the teaching practice among language educators a is more logic for students from collectivist societies to speak up in front of others in case they are permitted to do so. However, on the contrary, it is very common for students from individualist societies to speak up in class in response to questions asked by a teacher. Faced with those different culture dimensions, as to effectively engage students from different cultural background into class, language educator needs to adopt certain method to minimize this cultural gap. According to Hofstede (1986), in order to motivate students from collectivist culture to be as active as students from individualist culture, a teacher once adopted an activity by passing a pencil around in class to guarantee each student a chance of speaking up in class. Through this method, students from collectivist cultures could to some extent transform themselves from silent listeners into active participants in class. Meanwhile, as for language educators, it is an effective way to engage a whole class students from diverse cultures into the focused conversation in class.

\section{Language educators focus on the cultural aspects of weak uncertainty and strong uncertainty avoidance will also affect the effectiveness of their classroom practice.}

Moreover, language educators' concentration on the cultural dimension of weak and strong uncertainty avoidance could also impact the effectiveness of their classroom practice. According to Hofstede $(1986)^{[1]}$, students from weak uncertainty avoidance societies prefer to follow the ty avoidance could also impact the effectiveness of their classroom practice. According to Hofstede (1986)ators, it is an effective way to engage a whole class students from diverse cultu As for students, critical thinking and creative productions are highly encouraged. By contrast, students from strong uncertainty avoidance societies are inclined to follow a well-organized learning patterns abiding by rigid requirements, tasks and guidance given by their lecturers. In consideration of that cultural difference, it is more effective for language educator to allow students from strong uncertainty avoidance societies to follow their originally well-organized learning pattern instead of converting to any innovative learning patterns. A study by Holliday (as cited in Corbett, 2003) indicated that students' appreciation or decline to the innovative teaching style and learning pattern should be understood by both teachers and curriculum designers. In particular, Holliday (as cited in Corbett, 2003) argued that arning pattern should be understood by both teachers and curriculum designers. ong uncertainty avoidance societies to follow

Copyright (C) 2020 Xinyi Yang

doi: 10.18282/1-e.v9i4.1720

This is an open-access article distributed under the terms of the Creative Commons Attribution Non-Commercial License (http://creativecommons.org/licenses/by-nc/4.0/), which permits unrestricted non-commercial use, distribution, and reproduction in any medium, provided the original work is properly cited. 
their originally well-organize ${ }^{[2]}$. In view of that, simply adopting some new teaching method would not be a guarantee for the effective classroom practice. Typically, according to the following example cited by Holliday (as cited in Corbett, 2003), some Egyptian university lecturers once decided to replace the traditional styled lectures with hod, they cannot guarantee the effective classroom practice ${ }^{[3]}$. However, as a result, many students from strong uncertainty avoidance culture would not show respect to the teacher anymore, since those students only recognize a lecturer respectable when the lecturer teaches in a traditional way.

\section{Relationship of Language Educators to Classroom Practice}

Furthermore, as to secure an effective classroom practice, language educator should also integrate the cultural dimension of high and low power distance into his teaching practice. According to Hofstede (2001), the teaching practice in high power distance culture is teacher determined. Under this circumstance, to what extent a student can effectively pursue related knowledge is utterly relied on his teacher's qualification. And this happens even when students pursue more profound knowledge in universities. As Hofstede argued (2001) that in high power distance culture, teacher enjoys a leading position in the student and teacher relationship. As a result, students are more confined to the learning patterns directly given by their teacher. On the contrary, in the low power distance culture, it was cited by Hofstede $(2001)^{[4]}$ that students and teachers maintain a mutually equal relationship during teaching practice. And students play a center role in their pursuit of knowledge. Based on that, Xiao (as cited in Carmona, 2010) argued that since Chinese students and especially the Northeastern Asian students are more accustomed and confined to a ip. As a result, students are more confined to ave a difficult time to adapt themselves well in the t, Xiao (as cited in Carmona, 2010) argued that since Chinese students an ${ }^{[5]}$. In order to make the cross-cultural classroom practice more effective, language educator should be well aware of the fact that students from high power distance culture have difficult time in their adaptation to the more open and communicative-styled classroom practice. Once those students have hard time concentrating on the communicative classroom practice, they would regard it time-consuming and unworthy to pay any attention to the lessons, which would seriously affect their engagement in language classroom practice.

\section{Cross-cultural Differences in Language Education}

In conclusion, due to intercultural gap, it is common to notice that engaging language learners from cross-cultural background effectively into classroom practice can be complicated for a language educator. In consideration of that, as to make an effective classroom practice, language educators should firstly be aware of the cultural variability in class and then integrate those theories well into his teaching practice. Through this method, language educators could make their teaching more effective.

\section{Reference}

[1]Carmona, A. J. (Ed.). (2010). Language Teaching and Learning in ESL Education: Current Issues, Collaborations and Practice. North Carolina: Kona Publishing and Media Group.

[2]Corbett, J. (2003). An Intercultural Approach to English Language Teaching. Clevedon: Multilingual Matters.

[3]Gay, G. (2003). Culturally Responsive Teaching: Theory, Research, and Practice. New York: Teachers College Press.

[4]Hofstede, G. (1986). Cultural Differences in Teaching and Learning. International Journal of International Relation, 10(3), 301320 .

[5]Hofstede, G. (2001). Culture's Consequences: Comparing Values, Behaviors, Institutions an Organizations across Nations (2nd ed.). Thousand Oaks: Sage. 